\title{
Role of collaboration in green supply chains in the UK: An exploratory study on suppliers, logistics and retailers perspectives
}

Many companies around the world have started to realise that working alone will not be sufficient in their move towards a greener supply chain (SC). More specifically, recent UK government regulations on implementing strict $\mathrm{CO}_{2}$ reduction encourage $\mathrm{SC}$ operators to work collaboratively, in production and logistics or other operations, to achieve their green objectives. In this research, we look at some underlying factors of SC collaboration, focussing on suppliers, logistics and retailers, for the purpose of improving the environmental sustainability of companies' SCs. To facilitate our study, we conduct case studies in two overseas supplier companies with the aim of providing a better understanding of how green issues imposed by European and UK customers influence the companies' actions to meet agreed environmental goals. Based on the initial analysis of the case studies, we develop a conceptual framework which indicates that SC collaboration plays an important role in ensuring companies achieve environmental sustainability of their SCs. Subsequently, staff in middle-management and related roles in sixteen companies operating in the UK are interviewed. This allows us to understand their business practices in terms of SC collaboration with their suppliers and buyers to achieve the goal of $\mathrm{CO}_{2}$ reduction. Finally, drawing upon the information from company reports and websites, a number of UK leading retailers' actions to reduce $\mathrm{CO}_{2}$ emissions are investigated. We develop a conceptual framework of SC collaboration for environmental sustainability to help companies improve their level of collaboration between suppliers and buyers in terms of meeting their environmental objectives. The proposed framework will serve as a base model for the companies using or considering SC collaboration to achieve their environmental agendas, in line with governmental green regulatory requirements.

Keywords: supply chain, environmental sustainability, $\mathrm{CO}_{2}$ emissions, collaboration

\section{Introduction}

Environmental sustainability is emerging as an important factor affecting businesses. It is also one of the important critical success factors in the UK retail industry today. Different stakeholder groups, such as the government, consumers and the media, are putting pressures on the retailers to become increasingly environmentally responsible. Note that such governmental regulation covers many environmental topics, not just $\mathrm{CO}_{2}$ emissions; two recent examples being the Waste Electrical and Electronic Equipment (WEEE) Regulations (BERR, 2007) and the End-of-Life Vehicles (ELVs) Regulations (BIS, 2010). Companies in the UK retail sector have responded to environmental pressures by adopting various innovative strategies to become environmentally sustainable. In this research, we focus specifically on one such innovative strategy, namely facilitating collaboration among supply chain (SC) partners to assure environmentally sustainable SCs and to improve business performance. 
Supply chain collaboration is a leading business strategy in today's competitive business world. Indeed, to obtain maximum benefits, some SC players have started to form and practise collaborative partnerships across all of planning, production, forecasting and replenishment (Ramanathan and Muyldermans, 2010). Due to the recent awareness of environmental issues and governmental regulations, some companies also collaborate with other SC partners specifically for reducing $\mathrm{CO}_{2}$ emissions, either in production and logistics, or other operations (Oglethorpe, 2010). In recent years, some leading UK retailers such as Asda, Tesco, M\&S, and Debenhams have shown active involvement in reducing their carbon footprint. These retail SCs try to reduce carbon emissions in operations including raw material supply, production and logistics, while retail giants, such as Wal-Mart and Tesco, have the leverage to insist that their suppliers reduce carbon emission levels in products and transportation (Tesco News, 2012; Wal-Mart, 2010). To achieve this objective, many SC players have taken steps to build close collaboration across the entire SC.

However, in the existing literature there are few empirical studies on the role of SC collaboration in influencing the environmental sustainability strategies of UK retailers, and the impact of such collaboration on their business performance. Therefore, in this research our aim is to address this gap. To fulfil this, we investigated two supplier companies (manufacturers) to understand their current extent of collaboration with their suppliers and/or buyers in order to reduce $\mathrm{CO} 2$ emissions. We also examined the actions of several leading UK retailers and logistics companies. This allows us to have a better understanding of their current initiatives in $\mathrm{CO} 2$ reductions across their SCs. During this process, we pay particular attention to identifying the areas of SC operations that need collaborative support from SC partners in relation to the environmental sustainability of the business (Steckel et al., 2004). Based on this knowledge of companies' practice of collaboration in reducing $\mathrm{CO}_{2}$ emissions, we develop a conceptual framework of SC collaboration for environmental sustainability. This framework can serve as a base model to assist companies in achieving their environmental agendas in line with the governmental green regulatory requirements.

The remainder of this paper is organised as follows. Section 2 presents the research background, related literature and research method. Section 3 analyses the two case studies, which contribute to the development of a conceptual model. Section 4 discusses the findings from interviews with sixteen UK companies and provides an understanding of their business practices in terms of collaboration with suppliers and buyers in reduction of $\mathrm{CO}_{2}$ emissions. This section also discusses the actions by a number of UK leading retailers to reduce $\mathrm{CO}_{2}$ 
emissions in order to provide baseline data on the scope for current and planned improvements in the UK retail SC sustainability. Section 5 concludes and highlights our research findings, managerial implications, research limitations and possible future research.

\section{Background literature}

\subsection{Sustainable Supply Chain Management}

Since the 1997 Kyoto Protocol agreement, which set targets for 37 industrialised countries and the European community for reducing greenhouse gas (GHG) emissions (UNFCCC, 1997), there has been an increasing public and governmental concern for the environment. International organisations and national governments have set up GHG emission reduction targets for the next 10 to 50 years (e.g. the EU, a 20\% reduction by 2020; and the UK, in its Climate Change Act, an $80 \%$ reduction by 2050 , both targets are relative to 1990 emission levels). Since then companies have been under mounting pressures to reduce the environmental impact of GHG, to which $\mathrm{CO}_{2}$ is the primary contributor, in their SC activities. A wide variety of initiatives to reduce $\mathrm{CO}_{2}$ emissions are being currently used or considered in the UK SC operations, especially by larger companies which have available resources and capabilities. In the UK, a number of studies and reports regarding such initiatives are available. For example, useful reports have been produced by the Department of Energy and Climate Change (DECC), the Department for Environment, Food and Rural Affairs (DEFRA), the Carbon Trust, the Chartered Institute of Logistics and Transport (CILT), and the Social Research Council (SRC).

A review of the literature shows that there have been an increasing number of studies that look specifically at the environmental impacts of SC activities. Topics studied in this area include environmental impacts of freight transport (Cullinane and Edwards, 2010), the environmental impact of warehousing and distribution (Marchant, 2010), and the environmental costs of logistics (Piecyk, 2010). Specific practices that have an impact on carbon emissions include the use of green criteria to choose suppliers and transporters (Edwards et al., 2010), consolidation of shipments and selection of cleaner transport modes (Eglese and Black, 2010, McKinnon, 2010a, McKinnon and Edwards, 2010), the use of environmentally friendly packaging, recuperation of materials for reuse, and the disposal of waste (Cherrett et al., 2010). While there is an increasing understanding of companies' responses towards environmental issues, including $\mathrm{CO}_{2}$ emissions, there is still little understanding of the use of SC collaborations to reduce the impact of $\mathrm{CO}_{2}$ emissions on the environment. This is perhaps surprising, considering the importance of the SC in developing 
strategies for achieving lower emissions (Wu and Dunn, 1995, Ehrhart, 2010). Moreover, several authors have pointed out the need for the academic research to 'stay close to SC practice' in order to identify new perspectives to address the mainstream strategic concerns, including $\mathrm{CO}_{2}$ emissions (CCC, 2008, McKinnon, 2010b, 2010c).

The retail sector is large and dynamic in any economy. Retailing involves selling goods and services to public, and caters to a variety of consumers. According to the British Retail Consortium, the UK retail sector generates 8\% of the Gross Domestic Product and accounts for over $10 \%$ of the UK workforce, employing nearly 2.8 million people at the end of March 2009 (British Retail Consortium, 2012). Given the close association of retailing with transportation, it is also a highly polluting sector. In this era of 'green' SC, an increasing number of customers show concern about choosing products with lower carbon footprint (Oglethorpe, 2010). This, in turn, requires retailers and manufacturers to act as 'green initiators'; for example, many UK retailers (e.g. Sainsbury’s and Morrisons) try to buy from local farmers to reduce total travel distance (food miles) of the products. In addition, the recent green policies of the UK government have hastened companies' initiatives to reduce their carbon footprints before 2020; and as a result the idea of the green SC has become a common norm for many businesses. Moreover, to meet these green objectives, SC players have started to work together to achieve the companies' green agendas.

In specific cases, some companies feel the stakeholders' pressure in implementing green agendas; this indeed insists the companies to adopt environmental practices (Sarkis et al., 2010). Walker et al. (2008) discussed specific drivers and barriers to environmental supply chain management practices. They used both the public and private sectors for their study. A detail literature on sustainable supply chain management is available in Carter and Easton (2001) and Seuring and Muller (2008).

\subsection{Supply Chain Collaboration}

In this section, we express some of the key underlying factors of collaboration from the literature. Also, we highlight some of the issues identified from the literature and practice in implementing collaboration in the effort of improving performance.

In recent years, researchers have recognised collaboration among members of SCs as an effective strategy to improve performance of SCs, including performance in terms of environmental sustainability. Many businesses around the world have been practicing supply chain collaboration for many years for improving business performance such as reducing cost 
and increasing profit (Horvath, 2001; Barratt, 2004 ; Danese, 2007). Companies such as WalMart collaborate have transparent information exchange (electronic point of sales data) with Procter \& Gamble. Such supply chain collaborations help companies to improve forecasting accuracy (Aviv, 2007; Smaros, 2007; Ramanathan and Muyldermans, 2010). Level of collaborations will vary based on the intentions of partnerships (Larsen et al., 2003). Companies that collaborate for information sharing and forecasting may need to accept organisational changes, both internal and external to the company, to improve their performance (Barratt and Oliveira, 2001; Forme et al., 2007). This will help the SC partners in joint decision making. Companies that collaborate for timely replenishment need to be good in logistical performances (Simchi-Levi and Zhao, 2005; Chen and Paulraj, 2004).

In the literature of supply chain management, Vendor Managed Inventory (VMI), Efficient Consumer Response (ECR), Continuous Replenishment (CR) and Accurate response (AR) have been suggested to improve material and information flows in supply chains. (Fisher, 1997; Barratt and Oliveira, 2001; Sari, 2008). Given the increasing complexities of supply chains, and given the increasing sophistication in information technology and the use of the internet, a new supply chain management tool has emerged in the last few years for supply chain collaboration. This new tool is the so called Collaborative Planning, Forecasting and Replenishment (CPFR) framework. This framework exploits computer networking, information technology and other internet based technologies. But none of the above mentioned supply chain initiatives have considered carbon reduction or green supply chains as its core strategy for collaboration with supplier or buyers.

Some researchers studied manufacturing and retail sector to analyse performances of supply chains. Among these authors, Dehning et al. (2007) used secondary data in the US to analyse the financial performance effects of SC management systems in manufacturing firms; Evans (2007) studied the impacts of information management on business performance using an online survey; and Vachon and Klassen (2006, 2008) examined the role of SC collaboration on environmental management and manufacturing performance. Nyaga et al. (2010) examined the role of collaboration in supplier-buyer relationship in presence of commitment and trust.

Some SC partners seek a high level of collaboration, looking to exchange information widely, while others limit collaboration to selective areas such as product design, new product development and logistics (Khan et al., 2012; Van Hoek and Chapman 2007; Larsen et al., 2003; ECR Europe, 2002). In order to reduce carbon emissions, companies in general 
wish to know the carbon footprint of all the items they use both for production and replenishment. In effect, the relevant information needs to be exchanged among suppliers and buyers (Ramanathan, 2012). Many companies have started to realise that working alone will no longer be adequate to achieve green SC goals (Vachon and Klassen, 2006, 2008). Recent governmental regulations on implementing strict $\mathrm{CO}_{2}$ reduction have encouraged many $\mathrm{SC}$ operators to work collaboratively to achieve their green objectives.

Piecyk (2010) suggested the following critical success factors for carbon reductions: a) senior management support and devoting necessary resources; b) buy-in from all partners involved and a good level of cooperation across the SC; c) a timetable for the project with well-defined milestones for each of the phases in the carbon reduction process; d) employee involvement and understanding of the environmental impact of the carbon reduction issue. These factors are visible in the actions undertaken by the case companies investigated in this research. We use the knowledge gained through the literature and practices to develop our research method and hypothesis.

\subsection{Research objective and research method}

Based on the review of literature, there are few studies that have looked at the collaborative environmental behaviour of retail companies using empirical analysis (Carter and Easton, 2011). More specifically, there is very little research that focuses on the role of environmental pressures exerted by different stakeholders on the performance of retail companies. Our objective of this research is to identify SC collaborative arrangements among companies for environmental sustainability.

We examine:

- The various factors (including as stakeholders pressure) underlying SC collaboration, especially in terms of reducing $\mathrm{CO}_{2}$ emissions;

- Issues involved in maintaining environmentally sustainable SCs;

- Whether SC collaboration, initiated by environmental pressure, is likely to improve the commercial performance of the organisations involved.

To achieve these objectives we carry out case study research with two Indian supplier (manufacturing) companies that have collaborative business partnerships with European and UK companies; and hold interviews with sixteen logistics and related companies operating within the UK. Subsequently, because the retail sector via its own or third-part logistics suppliers is one of the main influences for SC collaboration, public-domain data have been 
gathered on current and proposed environmental initiatives across a number of large leading UK retailers.

The research investigations are conducted in three phases:

- Phase 1: Company case studies on initiatives of $\mathrm{SC}$ collaboration, $\mathrm{CO}_{2}$ emission policies and strategies, and future plans. The interviews in Phase 1 aims to give an overview of the supplier companies' perspectives and initiatives in obtaining green SCs. Phase 1 also helps form a conceptual framework of SC collaboration for environmental sustainability.

- Phase 2: Semi-structured interviews with middle-managers having roles in logistics, production and different other operations in sixteen companies operating in the UK. This is mainly to capture the role of SC collaboration and information exchange in creating and maintaining environmentally sustainable SCs in the UK. Analysis of interviews in Phase 2 broadened the framework developed in Phase 1.

- Phase 3: Investigations into the actions of a number of UK leading retailers to reduce $\mathrm{CO}_{2}$ emissions by drawing on information from company reports and websites. This provides baseline data on the scope for current and planned improvements in UK retail SC sustainability.

Table 1: Data collection

\begin{tabular}{|l|l|l|}
\hline \multicolumn{1}{|c|}{ Research investigation } & \multicolumn{1}{|c|}{$\begin{array}{c}\text { Companies/people } \\
\text { involved }\end{array}$} & \multicolumn{1}{|c|}{ Data source (period) } \\
\hline 2 case studies & Indian companies & India (2012) \\
\hline $\begin{array}{l}16 \text { semi-structured } \\
\text { interviews }\end{array}$ & $\begin{array}{l}\text { Middle managers of } \\
\text { UK-based companies }\end{array}$ & $\begin{array}{l}\text { Exhibitors of Logistics Link } \\
\text { South } \\
\text { NEC, Birmingham (Feb 2013) }\end{array}$ \\
\hline $\begin{array}{l}\text { Review of published UK } \\
\text { company documents }\end{array}$ & UK leading retailers & $\begin{array}{l}\text { Company reports, \& other } \\
\text { published sources (2012-13). }\end{array}$ \\
\hline
\end{tabular}

\section{Development of case studies and conceptual model}

In this era of growing environmental awareness, an increasing number of customers place importance on choosing products with a lower carbon footprint (Oglethorpe, 2010). This is one reason why UK retailers and manufacturers themselves are paying increasing attention to environmental initiatives. For example, the food retailers such as Sainsbury's and Morrisons, aim increasingly to buy from local farmers, to reduce the total travel distance ('food-miles') of their farm-sourced products. A particular pressure has been government policies that have hastened companies' initiatives to reduce $\mathrm{CO}_{2}$ emissions. In the $\mathrm{UK}$, for 
instance, in 2009 the Government announced it commitments to achieving a 34\% reduction in $\mathrm{CO}_{2}$ emissions by 2020, compared to the levels in 1990 (BIS, 2012). For these two reasons, as well as the pressures of media scrutiny and companies' own understanding of the threats to their business, and to society, from climate change, seeking a 'green' SC has become part of the mainstream strategy of many businesses.

As discussed earlier, to achieve the objective of $\mathrm{CO}_{2}$ reduction, many companies are seeking to collaborate with their SC members. However, as SC collaboration is a relatively new initiative, it is important to ensure that there is a good level of information exchange among SC partners so as to minimise inefficiencies (such as the build-up of inventory) in the SC. Increasing efficiency not only improves the company's environmental performance, but can also often improve the financial bottom line of a company.

In order to reduce carbon emissions, companies need to know the carbon footprint of the items they use for production and replenishment. To assist in provision of this knowledge, the British Standards Institution has recently issued PAS 2050: 2011. This is a tool that helps companies carry out internal assessments of the existing life-cycle GHG emissions of the products in their SCs, so as to identify 'hotspots' and other cost/energy saving opportunities; evaluate alternative product configurations, sourcing and manufacturing methods, raw material choices and supplier selection; devise ongoing programmes aimed at reducing GHG emissions; and report on corporate responsibility (BSI, 2011). In SC collaboration, such information on products needs to be exchanged among suppliers and buyers along the chain if the scope for collaboration is to be fully understood. This is further discussed through case studies in the following sections.

\subsection{Case studies}

\section{Case study 1 - A bag manufacturing company (Company A)}

The first case study is a bag manufacturing company (company A) in Mumbai, India. Company A operates globally providing recyclable bags for wholesalers and distributors of pharmaceutical, textile and food products to UK and other European markets. The company also makes 'jumbo size' bags for exporting heavyweight machinery. Company A's UK and European buyers impose certain environmental requirements on the company to provide fully recyclable bags to maintain green SCs. To continue business with European market, the company A needs to fulfil various requirements from its buyers. For example, some customers insist on bags made of $100 \%$ recycled material, while others require the bags that 
can be recycled but are not necessarily made from recycled materials. As companies are now seeking to establish themselves as environmentally sustainable, company A must discuss the green issues with their buyers before their orders are placed. In the last 5-6 years, company A has established such collaborative relationships with over $50 \%$ of its buyers. This has mainly been achieved as a result of the following factors.

- Government regulations on environmental sustainability

- Stakeholders' pressure

- Government incentives

- Buyers' strategy changes in requiring recyclable and recycled products

- Increased competition in the market of sustainable SC

- Company's internal forces to sustain in the market

- Long- term business objectives

The recent green agendas of the supplier' local government (Indian Government) have also forced company A to introduce reverse logistics into its overall SC processes. The company now is actively engaged in recycling the returned end-of-life products from their clients. Company A uses 'backward integration' in terms of converting the returned polypropylene bags into fabric, which is used in turn as an important ingredient of the jumbo bags. In addition to reducing the environmental impact, this backward integration also helps the company save on cost of raw materials, and has made the company self-sufficient in terms of raw material requirement for making jumbo bags. In addition, the process of backward integration has helped the company reduce its product lead-time considerably (a 20-25\% reduction), and also improve its production flexibility. Company A's approach on flexible production and adaption to the new demands has helped improve its reputation. In the past five years, the company has established its SC collaboration with about 100 suppliers and over 200 buyers. In achieving the target of the reduction in $\mathrm{CO} 2$ emission, Company A has also improved its business performance in sales by $24 \%$. and production efficiency by $22 \%$.

For many SCs, one of the important factors of collaboration has been information exchange (Ramanathan, 2012). Initially, at the inception of SC collaboration, company A used to have fairly restricted information exchange. However, over the last three years the company has increasingly followed a policy of more transparent information exchange, especially in the production process. Both buyers and suppliers of the company are being actively engaged in suggesting different technically- achievable ways to reduce carbon emissions in the 
production and replenishment stages of the business. On a regular basis the following information is being exchanged within company A's SC:

- Sales demand data for normal and recycled products

- Product requirements in terms of carbon emissions (raw material, production, packing and transportation)

- Green policies of the customer companies

- Business goals of achieving $\mathrm{CO}_{2}$ reduction

- Updated list of stakeholders and their involvement in achieving the above goals

Company A stressed it aims to achieve a 50\% reduction of $\mathrm{CO}_{2}$ emissions associated with production activities within 10 years, and a $25 \%$ reduction from logistics related activities within 15 years;

The environment-friendly production approach of company A has attracted many customers from around the world. To retain these customers and further improve customer satisfaction, company $\mathrm{A}$ is investigating other incentives across its entire SC, including offering increased information exchange, profit-sharing schemes, and targeted price discounts. This case study has demonstrated that company A has clearly understood the importance of SC collaboration, and acted on this in concrete ways, particularly in terms of lowering CO2 emissions during manufacturing, packing and transportation, and meeting agreed collaborative goals on product recycling and recyclability, and product remanufacturing.

\section{Case study 2 - A food provision company (Company B)}

The second case study -a food provision company (company B), is also located in Mumbai, India. Company B exports its products to many companies in Europe, Australia and the US. The main products are freshly frozen tropical vegetables that offered as ready-toserve cooked meals in frozen packs. A big challenge for company B is to cater for the specific requirements of buyers from different countries in terms of ingredients and recyclable packaging. As the majority of its customers are from western countries, the basic requirements are two-fold: products with low $\mathrm{CO}_{2}$ emissions in their production; and very importantly, the packaging of the frozen products must be with $100 \%$ recyclable materials. To achieve the target of low $\mathrm{CO}_{2}$ emissions and low cost at the same time, Company $\mathrm{B}$ secures its main raw materials (such as vegetables, meat and milk) from two sources. Company B owns some farms that supply about $30 \%$ of its raw material required, and it purchases the remaining $70 \%$ from local farmers. One of the major requirements of frozen vegetables is to be packed within two hours of harvesting. This is achieved by company B as 
it uses a packaging facility close to the farmers' fields. This approach guarantees the 'freshly frozen' nature of the products supplied. The vegetables, high quality pulses, and meat are transported to its production plant which is located within 50 kilometres of the sources. Within the next 12 to 18 hours, these ingredients are processed into the final meals and packed into freezer bags. These bags are made of $100 \%$ recycled products as required by the company's main clients. The finished meal products are stored in freezers at -18 degrees centigrade until they are sent to buyers. Company B aims to load these items into trucks from the freezer facility within 24 hours of packing, and then sends them to its buyers either by ship cargo or air freight cargo, depending on the agreements between company B and its buyers. In order to reduce $\mathrm{CO}_{2}$ emissions along its $\mathrm{SC}$, company $\mathrm{B}$ exchanges information, including sales quantities and green policies, with its SC partners on a regular basis. Information on possibility of $\mathrm{CO}_{2}$ reduction in raw-materials, production and distribution is shared among SC partners to improve green performance of the company.

Although initial investment in $\mathrm{CO}_{2}$ reduction is high, Company $\mathrm{B}$ has proved that through collaborative SC activities it is possible to achieve both the green objectives and improved sales. The SC collaboration can also yield a profit on recycled products such as packaging materials. While company B had already initiated and achieved some degree of $\mathrm{CO}_{2}$ reduction in its operations. Now businesses in these markets view low $\mathrm{CO}_{2}$ in production and logistics as a necessary part of their business plan. For example the Managing Director of company B said:

"When we obtained the European and UK business contracts for frozen food, one of the main pre-conditions was reduced $\mathrm{CO}_{2}$ in all our operations".3.2. Conceptual model development

In every business, stakeholder pressures often make a great difference in terms of speeding up the implementation of policies; and environmental pressures from the government and buyers especially can accelerate the implementation of green SC strategies. From the interaction with the case companies (Company A and Company B), we can see the influence of environmental pressures that encourage them to be involved in green SC collaboration. These collaborations are expected to improve the business performance of all SC partners involved in the collaboration.

Figure 1: The role of green SC collaboration. 


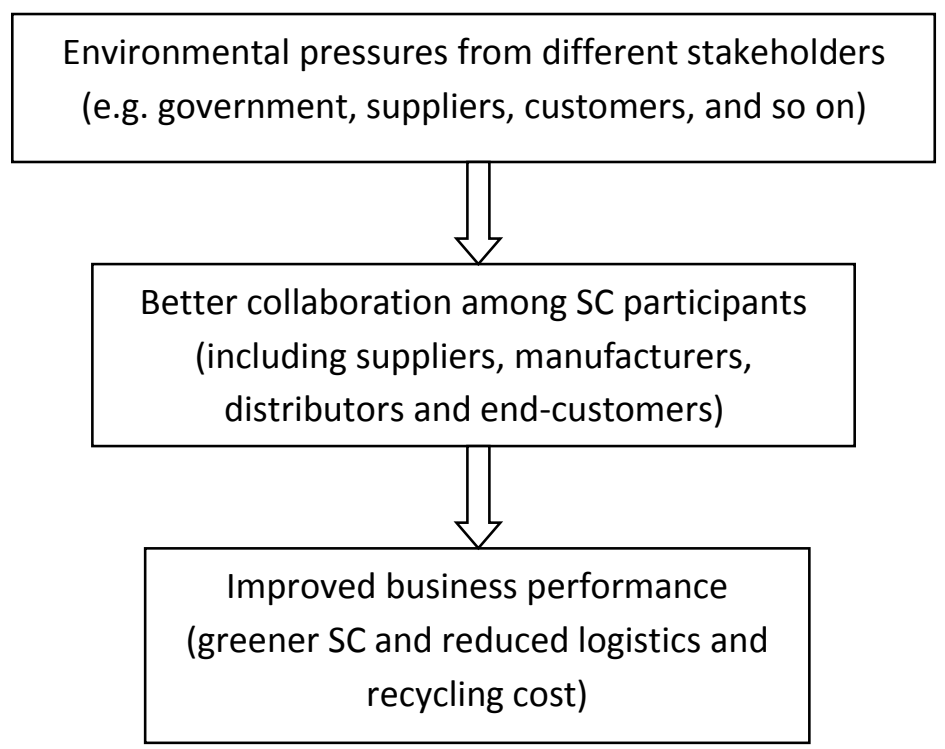

Figure 1 presents a simple conceptual model of the role of SC collaboration to achieve greener SC. The model implies that the information exchange across the SC constitutes the change or modification of business strategies and targets of the various partners of the SC, based on the agreed carbon footprint data on products and services, forecasts of shipments and method of shipments, and the initiatives implemented by one or more partners to achieve desired 'green' SC. It is recognised that reducing a SC's carbon footprint is a very challenging task, particularly when it involves actions by various parties across the entire SC. Therefore, achieving such a goal should be perceived as an on-going long-term project that is worth pursuing because it is likely to bring benefits to all the players involved. 


\section{SC collaboration analysis and discussions}

\subsection{Stakeholders pressure and levels of SC collaboration}
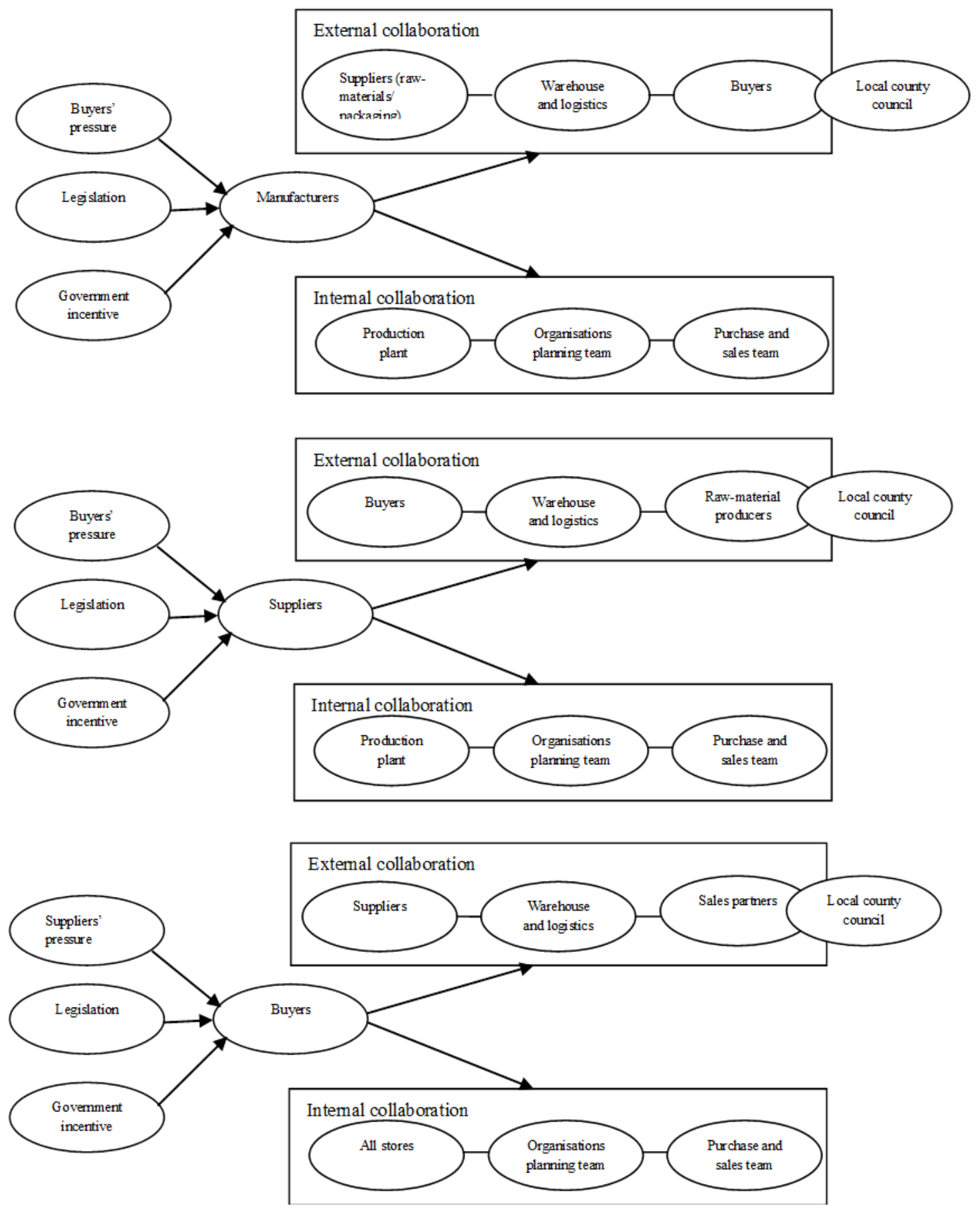

Figure 2: Stakeholders pressure and supply chain collaboration

Figure 2 represents different types of stakeholders' pressure for manufacturers, suppliers, and buyers to get involved in SC collaboration. 
The level of collaboration among players to achieve 'green' $\mathrm{SC}$ is indirectly represented through business strategies. Ramanathan (2012) suggested three levels of collaboration for businesses, namely preparatory level, progressive level and futuristic level. We use the same classification for our research to indicate three levels of collaboration for environmentally sustainable SCs. Based on the time-span for implementing business plans of the two case companies investigated in this research, we classify strategies as follows: plans to be achieved in less than 3 years as 'short-term', plans to be achieved in 3-6 years as 'medium-term' and plans to be achieved 6-10 years as 'long-term'. In general, both case study companies we investigated had a common agenda of reducing carbon emissions in five main operational areas, namely materials, production, supply, distribution, and technology, and any other general operations. Based on these observations, the authors identified the classification of three different levels of green SC collaboration for the six? operational areas (see Table 2).

Table 2: Suggested levels for green supply chain collaboration

\begin{tabular}{|c|c|c|c|}
\hline & \multicolumn{3}{|c|}{ Green supply chain collaboration } \\
\hline & $\begin{array}{c}\text { Preparatory level } \\
\text { (Short-term - within } 3 \text { years) } \\
\end{array}$ & $\begin{array}{c}\text { Progressive level } \\
\text { (Medium-term - 3-6 years ) }\end{array}$ & $\begin{array}{c}\text { Futuristic level } \\
\text { (Long-term plan - 6-10 years) }\end{array}$ \\
\hline Materials & $\begin{array}{l}\text { identify the best possible } \\
\text { way of sourcing and } \\
\text { transportation to reduce } \\
\mathrm{CO} 2\end{array}$ & $\begin{array}{l}\text { keep on looking for new } \\
\text { materials to reduce carbon } \\
\text { emission }\end{array}$ & $20 \% \mathrm{CO}_{2}$ reduction \\
\hline Production & $\begin{array}{l}\text { identify the best possible } \\
\text { method of production in- } \\
\text { house or outsource }\end{array}$ & $\begin{array}{l}\text { keep changing the production } \\
\text { process to maintain low } \\
\text { carbon emissions }\end{array}$ & $20 \% \mathrm{CO}_{2}$ reduction in 3 years) \\
\hline $\begin{array}{c}\text { Supply } \\
\text { (raw material) }\end{array}$ & $\begin{array}{l}\text { check the suitability of } \\
\text { supply }\end{array}$ & $\begin{array}{l}\text { keep updating the supply } \\
\text { quality in line with carbon } \\
\text { emission level) }\end{array}$ & to ensure carbon free supply \\
\hline $\begin{array}{l}\text { Distribution } \\
\text { (logistics and } \\
\text { warehousing) }\end{array}$ & $\begin{array}{l}\text { identify the best possible } \\
\text { logistics operator }\end{array}$ & $\begin{array}{l}\text { search for new energy options } \\
\text { and update }\end{array}$ & $\begin{array}{l}20 \% \mathrm{CO}_{2} \text { reduction in } 3 \text { years) } \\
\text { Long-term plan (achieve carbon- } \\
\text { free objective) }\end{array}$ \\
\hline $\begin{array}{c}\text { Technology } \\
\text { (manufacturing } \\
\text { and distribution) }\end{array}$ & $\begin{array}{l}\text { develop and test new } \\
\text { technology in place ) }\end{array}$ & $\begin{array}{l}\text { test and update technology } \\
\text { periodically }\end{array}$ & $\begin{array}{l}\text { to sustain with new technology } \\
\text { innovation }\end{array}$ \\
\hline $\begin{array}{l}\text { General } \\
\text { operations }\end{array}$ & $\begin{array}{l}\text { develop corporate plans for } \\
\mathrm{CO}_{2} \text { reduction }\end{array}$ & $\begin{array}{l}\text { update operations strategies } \\
\text { periodically to reduce } \mathrm{CO}_{2}\end{array}$ & $\begin{array}{l}\text { ensure all in-house and external } \\
\text { operations are carbon-free }\end{array}$ \\
\hline
\end{tabular}


In Table 2, the preparatory level of collaboration assists the companies in engaging in the development of commonly achievable green policies for their SC. At this level, companies are ready to exchange their plans and strategies with their SC partners. At the progressive level, the companies may have already implemented some of the green policies with the support from their SC members in order to achieve long-term business objectives. Detailed reports on on-going implementation and necessary operations or policy changes will be discussed at this level. The futuristic level of collaboration encourages SC partners to provide continuous support throughout the process of carbon reduction with open information exchange on daily or weekly basis.

These three levels of collaboration can be applied by companies to develop a common framework of different levels of collaboration to achieve green SCs. Companies with compelling short term plans to implement green policy in less than 3 years preferably choose futuristic level of collaboration. This gives a comfortable position for a company to achieve $\mathrm{CO}_{2}$ reduction. Any company planning to adopt a green SC will get involved in preparatory level of collaboration to make updates on technology, supply, logistics, production and other operations. This will continue for 3 to 6 years, if necessary some companies may extend this period further to ensure a sustainable level of carbon reduction. Preparatory collaboration prepares companies to get involved in SC collaboration with other players for the purpose of carbon reduction in operations with a final objective of achieving sustainable green SCs. Both company A and company B confirm that they seek to maintain a 'futuristic' level of collaboration with upstream and downstream SC partners. Further discussions with the companies highlight the underlying factor of buyers' pressure as the main reason for such a strong collaborative initiative. Both case companies view their businesses with the UK companies as a profitable long-term partnership plan. In order to maintain this partnership, both companies are happy to be involved in achieving green SCs; and recognise that this approach is likely to bring them additional future business from the UK, the USA, Europe and Australia.

\subsection{Green initiatives of small and medium size companies in the UK logistics and transport sector}

An investigation was then carried out at a large logistics exhibition held annually in the UK. We conducted semi-structured interviews with middle-level managers from sixteen small and medium sized companies participating in the UK logistics and transport sector. We used a random sampling method to choose participants for this study as this was very 
convenient in the large logistics exhibition arena. The aim is to understand the current policies being followed by these companies in terms of a green agenda and in particular, $\mathrm{CO}_{2}$ reduction, and to find out the extent that SC collaboration is a part of these initiatives.

The combined views of these companies on their ability to control carbon reduction in raw material supply, production, warehousing and replenishment are given in Table 3. In addition, the table gives responses to a question about the extent that these companies feel under pressure from their final customers (the retailers) to reduce $\mathrm{CO}_{2}$ emissions in their SCs. It can be seen that, as would be expected, small production companies report that they do not have much control over $\mathrm{CO}_{2}$ reduction in distribution and warehousing, as they often do not own these facilities. Meanwhile, transport companies have a high (above 60\%) or very high (above $70 \%$ ) level of control in this area, but where passenger transport companies have higher control than freight transport in carbon reduction. Interestingly, in response to the question on pressure for $\mathrm{CO}_{2}$ reduction from the retailers, logistics companies indicated a higher level of pressure in maintaining green SCs than did producers, despite the fact that much of $\mathrm{SC} \mathrm{CO}_{2}$ emissions are indeed a result of producers' activity.

Table 3: Ownership of $\mathrm{CO}_{2}$ emission

\begin{tabular}{|c|c|c|c|c|c|c|}
\hline $\begin{array}{l}\mathrm{CO}_{2} \text { related } \\
\text { business objectives }\end{array}$ & 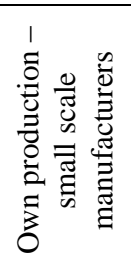 & 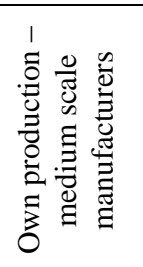 & 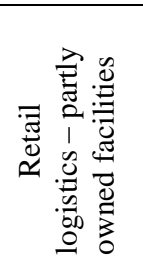 & 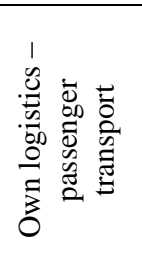 & 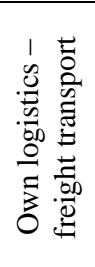 & 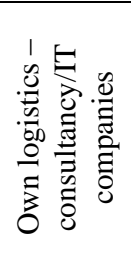 \\
\hline $\begin{array}{l}\mathrm{CO}_{2} \text { reduction in supply side } \\
\text { (purchase of raw materials) }\end{array}$ & Medium & Very high & Low & Very high & High & Very low \\
\hline $\mathrm{CO}_{2}$ reduction in production & Medium & Medium & Low & Very high & High & Medium \\
\hline $\begin{array}{l}\mathrm{CO}_{2} \text { reduction in demand from } \\
\text { retailers }\end{array}$ & Medium & High & Very high & Very high & High & Very low \\
\hline $\mathrm{CO}_{2}$ reduction in warehousing & Very low & Medium & Medium & Very high & High & Very low \\
\hline $\begin{array}{l}\mathrm{CO}_{2} \text { reduction in replenishment } \\
\text { (distribution side) }\end{array}$ & Very low & Low & Medium & Very high & High & Very low \\
\hline
\end{tabular}

Note: Very high - above $70 \%$; high -above $60 \%$; medium - above $40 \%$; Low-above $25 \%$; very low - less than $25 \%$

Turning now to SC collaboration, it is recognised that in order to meet government and stakeholder pressures for $\mathrm{CO}_{2}$ reduction, many companies in the $\mathrm{UK}$ have sought the help of their logistics partners so as to reduce the use of fuel, and to minimise the number of delivery trips. For example, retailers make orders based on economic order quantity calculations, as this helps in obtaining the incentives available for bulk ordering and in reducing energy use in transport. However, bulk ordering affects the cost of carrying stock, 
and this in turn is a big challenge for retailers, especially when the demand is fluctuating. To handle this situation, retailers can seek closer collaboration with their upstream SC partners, assuring the right quantity at the right time' in the SC (Ramanathan, 2012).

However, while such collaborations can assist in managing supply issues, they may not always guarantee the reduction in $\mathrm{CO}_{2}$ emissions. In the recent $\mathrm{SC}$ collaborations in the mainstream retail sector, Tesco and Asda insist on suppliers achieving reduced carbon emissions in their production, packaging and logistics activities. We have learnt from the interviews with sixteen UK logistics and transport companies that the major factors for adopting a green SC were environmental pressures from different stakeholders, such as government, shareholders, suppliers and buyers. The interviews revealed that the company policies adopted in this area are clear reflection of the views of the stakeholders, and that these policies help them survive against the competition.

\subsection{Green initiatives of big retail companies in the UK}

In this Section, we examine current and planned green initiatives (again particularly in terms of $\mathrm{CO}_{2}$ reduction) of a number of UK retailers. This study helped to comprehend the picture of $\mathrm{CO}_{2}$ reduction in the UK retail SCs and the degree of collaboration between SC partners in achieving $\mathrm{CO}_{2}$ reduction.

Table 3 illustrates that leading UK retailers, such as Tesco and Asda, are currently significantly engaged in carbon reduction initiatives in the operational areas of distribution and logistics. Other retailers and wholesale businesses, such as B\&Q and John Lewis Partnership, have initiated $\mathrm{CO}_{2}$ reduction in the areas of their controllable operations, such as in-store heating and truck loads.

However, it was not very clear from this literature how manufacturers are planning to reduce $\mathrm{CO}_{2}$ in production. Some companies such as B\&Q and Alliance Boots have initiated several steps in reducing the use of energy. B\&Q has made a big investment in renewable energy projects, while Alliance Boots started its internal contribution of carbon reduction by using less energy in in-store operations. Tesco has started using rail transport, instead of road transport, to reduce its carbon emissions and road congestion. Lucy Neville-Rolfe, Executive Director of Corporate \& Legal Affairs at Tesco expressed the company’s progress towards its long-term targets of reducing $\mathrm{CO}_{2}$ emissions to become a 'zero-carbon business' by 2050 (Tesco News releases, 2012). B\&Q is planning to reduce its domestic haulage and business travel dramatically, by up to $50 \%$. Alliance Boots is using Telematics' technology across its 
fleet of vans to help monitor and manage $\mathrm{CO}_{2}$ performance. Increased awareness about environmental sustainability (especially in reducing carbon emissions) is creating a new front for competition among businesses. UK retailers such as Tesco, Asda, and Sainsbury's are competing to provide greener image, to prove that they are the most environmentally responsible leading UK retailers. 
Table 4: Company initiatives for improving environmental sustainability

\begin{tabular}{|c|c|c|c|}
\hline Company & Targets and strategies & Current initiatives & Achievements \\
\hline \multirow[t]{3}{*}{$\begin{array}{l}\text { B\&Q } \\
\text { Source: } \\
\text { B\&Q's One Planet } \\
\text { Home Action Plan } \\
\text { (October 2012) }\end{array}$} & $\begin{array}{l}90 \% \text { reduction in } \mathrm{CO}_{2} \\
\text { emissions by } 2023 \\
\text { Zero carbon electricity across } \\
\text { all } \mathrm{B} \& \mathrm{Q} \text { sites and } 90 \% \\
\text { reduction in heating fuels } \\
\text { (mainly gas) across all } \mathrm{B} \& \mathrm{Q} \\
\text { sites by 2023. }\end{array}$ & $\begin{array}{l}\text { - Reduce energy use in line with carbon footprint } \\
\text { reduction target of } 20 \% \text { by } 2012 \text {. } \\
\text { - All new stores to be zero carbon by } 2012 \text {. } \\
\text { - Thermostats in stores were reduced from } 20^{\circ} \mathrm{C} \text { to } 17^{\circ} \mathrm{C} \\
\text { during the day and from } 16^{\circ} \mathrm{C} \text { to } 15^{\circ} \mathrm{C} \text { for night time in } \\
2009 \text {. }\end{array}$ & $\begin{array}{l}\text { - B\&Q was one of the first } 12 \text { organisations to be awarded the } \\
\text { Carbon Trust standard in } 2008 \text { and was recertified in } 2011 \text { for } \\
\text { achieving year-on-year reductions in energy use. } \\
\text { - Investment in off-site renewable energy projects. } \\
\text { Focus: Carbon reduction in routine activities }\end{array}$ \\
\hline & $\begin{array}{l}\text { Zero waste }- \text { cut } \mathrm{CO}_{2} \\
\text { emissions from waste to } \\
\text { landfill by } 98 \% \text {. }\end{array}$ & $\begin{array}{l}-90 \% \text { of waste reused, composted or recycled by } 2012 \text {. } \\
-50 \% \text { reduction in waste to landfill by } 2012 \text {. }\end{array}$ & $\begin{array}{l}\text { - Invigorated environment champions programme with specific } \\
\text { emphasis on reducing store impacts such as achieving } 90 \% \text { recycling. } \\
\text { - Removed general waste skips and introduced segregated recycling } \\
\text { facilities to the stores. } \\
\text { - Working with the commercial team to reduce waste generation. } \\
\text { Focus: Extend collaboration with local councils and others for } \\
\text { recycling waste products }\end{array}$ \\
\hline & $\begin{array}{l}\text { Sustainable transport } \\
\text { (including Business travel, } \\
\text { haulage and staff travel - } 50 \% \\
\text { reduction in total travel } \mathrm{CO}_{2} \\
\text { emissions by } 2023 \text {. }\end{array}$ & $\begin{array}{l}\text { - 50\% reduction in flights within Great Britain by } 2012 \text {. } \\
-50 \% \text { reduction in } \mathrm{CO}_{2} \text { emissions from business travel } \\
\text { and domestic haulage by } 2023 \text {. }\end{array}$ & $\begin{array}{l}\text { - The introduction of double deck trailers to maximise the loads } \\
\text { carried, training drivers, reducing speeds and improved route } \\
\text { planning resulted in a } 22 \% \text { reduction in } \mathrm{CO}_{2} \text { emissions from logistics } \\
\text { in } 2010 \text { against the } 2006 \text { baseline. } \\
\text { - One of the distribution centres is being relocated to achieve a } \\
\text { projected savings in diesel consumption and } \mathrm{CO} 2 \text { emissions of } 14 \% \text {. } \\
\text { Focus: Collaboration from within and outside the company for } \\
\mathrm{CO}_{2} \text { reduction in logistics }\end{array}$ \\
\hline $\begin{array}{l}\text { John Lewis } \\
\text { Source: Corporate } \\
\text { Social Responsibility } \\
\text { Report } 2011 \text { (John } \\
\text { Lewis Partnership, } \\
\text { 2011) }\end{array}$ & $\begin{array}{l}\text { Reduce } \mathrm{CO}_{2} \text { emissions by } 15 \\
\text { percent on } 2005 \text { levels by } \\
2013\end{array}$ & $\begin{array}{l}\text { John Lewis is working towards delivering a } 15 \text { per cent } \\
\text { reduction in energy related transport } \mathrm{CO}_{2} \text { emissions from } \\
\text { deliveries by } 2013 / 14 \text {, against their } 2005 / 06 \text { baseline. }\end{array}$ & $\begin{array}{l}\text { - John Lewis achieved } 5.9 \% \mathrm{CO}_{2} \text { reduction per million sales since } \\
2005 / 06 \text { and } 20 \% \text { reduction by } 2011 \text {. } \\
\text { - John Lewis also corroborates the circa } 4 \% \mathrm{CO}_{2} \text { emissions reduction } \\
\text { with the introduction of the } 53 \mathrm{mph} \text { speed limit in their fleet. They are } \\
\text { also expecting to save } 4 \% \text { of } \mathrm{CO}_{2} \text { per vehicle with the introduction of } \\
\text { driver training. } \\
\text { Focus: Collaboration from within and outside the company for } \\
\mathrm{CO}_{2} \text { reduction in logistics }\end{array}$ \\
\hline $\begin{array}{l}\text { Alliance Boots } \\
\text { Source: Corporate } \\
\text { Social Responsibility } \\
\text { Report 2010/11 } \\
\text { (Alliance Boots, } \\
\text { 2012) }\end{array}$ & $\begin{array}{l}\text { Aim to reduce energy usage } \\
\text { wherever possible, and utilise } \\
\text { alternative, less carbon } \\
\text { intensive energy consuming } \\
\text { equipment }\end{array}$ & $\begin{array}{l}\text { - Implemented 'Telematics' technology across its fleet of } \\
\text { vans to help monitor and manage } \mathrm{CO}_{2} \text { performance. } \\
\text { - Boots uses the Multi-deck Urban Delivery (MUD) } \\
\text { trailer to reduce the environmental impacts of product } \\
\text { delivery. } \\
\text { - Reduced the level of non-essential business travel } \\
\text { through increased usage of the Group-wide video- } \\
\text { conferencing system. }\end{array}$ & $\begin{array}{l}\text { - In August 2009, Boots UK launched an awareness campaign aimed } \\
\text { at reducing energy use in its retail stores. } \\
\text { - Total } \mathrm{CO}_{2} \text { emissions produced by the Group for the year ended } 31 \\
\text { March } 2011 \text { were } 416,391 \text { tonnes, compared with } 420,822 \text { tonnes the } \\
\text { previous year. } \\
\text { - MUD alone has generated an estimated annual saving of nearly half } \\
\text { a million kilometres and approximately } 350 \text { tonnes of } \mathrm{CO}_{2} \text { in } 2011 \text {. } \\
\text { - Reduce the volume of goods imported into UK using airfreight. }\end{array}$ \\
\hline
\end{tabular}




\begin{tabular}{|c|c|c|c|}
\hline & & & Focus: Reduction of $\mathrm{CO}_{2}$ in logistics and business travel \\
\hline $\begin{array}{l}\text { TESCO } \\
\text { Source: TESCO } \\
\text { Corporate } \\
\text { Responsibility Report } \\
(2011)\end{array}$ & $\begin{array}{l}\text { Zero-carbon business by } \\
\text { 2050 10\% } \\
\text { Aimed in } 2007 \text { to cut } \mathrm{CO}_{2} \text { by } \\
10 \% \text { each year till it had } \\
\text { achieved a } 50 \% \text { reduction }\end{array}$ & $\begin{array}{l}\text { - Shift from road to rail e.g. established a rail link } \\
\text { between Daventry and Grangemouth. } \\
\text { - Utililise a barge link on the Manchester Ship Canal and } \\
\text { increase in double-deck trailers. } \\
\text { - Reduced level of Empty Running of trucks. } \\
\text { - Switched more than } 90 \% \text { its fleet of } 2,000 \text { tractors and } \\
4500 \text { trailers to B50 Biodiesel and is also evaluating } \\
\text { using hybrid vehicles in its transport system. } \\
\text { - In } 2007 \text {, Tesco also replaced six smaller distribution } \\
\text { centres with three larger ones. }\end{array}$ & $\begin{array}{l}\text { - The train links results in over } 8,000 \text { less tonnes of } \mathrm{CO}_{2} \text { a year and } \\
\text { saved over } 6 \text { million road miles each year since } 2007 \text {. } \\
- \text { Removed } 263,000 \text { miles from road travel and saved } 330 \text { tonnes of } \\
\mathrm{CO}_{2} \text { a year. } \\
\text { - Double-deck trailers save over } 12.5 \text { million miles and reduces } \\
17,000 \text { tonnes of } \mathrm{CO} 2 \text { per year. } \\
\text { - Reduced fuel consumption by up to } 10 \% \text { E.g. Vehicle speed limited } \\
\text { to } 50 \text { mph alone saves } 3 \% \text { on fuel consumption. } \\
\text { Focus: Strong collaboration for } \mathrm{CO}_{2} \text { reduction in logistics }\end{array}$ \\
\hline $\begin{array}{l}\text { ASDA } \\
\text { Source: Sustainability } \\
2.0 \text { (ASDA, 2011) }\end{array}$ & $\begin{array}{l}\text { - Cut emissions from existing } \\
\text { stores by } 20 \% \text { by } 2010 \text {, and } \\
\text { new stores by } 30 \% \text { by } 2013 \\
\text { - Target to send zero waste to } \\
\text { landfill by the end of } 2010\end{array}$ & $\begin{array}{l}\text { - Reduce waste by combination of food innovation, } \\
\text { removing unnecessary waste, and the introduction of } \\
\text { double-deck trailers, reverse logistics from its stores. } \\
\text { - Trial a refillable fabric conditioner dispenser, where } \\
\text { customers can refill their } 1.5 \mathrm{~L} \text { pouches up to } 10 \text { times. } \\
\text { - Shift store lighting to energy-efficient compact } \\
\text { fluorescent light bulbs. } \\
\text { - Working in partnership with CBA CGM, the leading } \\
\text { international rail freight provider. } \\
\text { - Aim to deliver full load, fast transit aiming at carbon } \\
\text { dioxide reduction. }\end{array}$ & $\begin{array}{l}\text { - } 28.7 \% \text { reduction in } \mathrm{CO} 2 \text { achieved by } 2011 \text { and saved over } 80,000 \\
\text { tonnes of } \mathrm{CO}_{2} \text { equivalent since } 2007 \text {. } \\
\text { - Saved nearly 40p per refill and reduced the amount of plastic } \\
\text { packaging waste by up to } 96 \% \text {. } \\
\text { - Diverted } 200,000 \text { tonnes of waste compared to } 2005 \text {. } \\
\text { - Introduced comprehensive staff recycling facilities allowing all its } \\
\text { store and depot staff to recycle plastic bottles, cans and office paper. } \\
\text { - Reduced, recycle, and reuse all of the materials in its stores and } \\
\text { depots. } \\
\text { Focus: Reducing } \mathrm{CO}_{2} \text { in local operations and waste recycling }\end{array}$ \\
\hline $\begin{array}{l}\text { United Biscuits } \\
\text { Source: } \\
\text { Environmental } \\
\text { Sustainability (United } \\
\text { Biscuits, 2011) }\end{array}$ & & $\begin{array}{l}\text { It has been working with the Royal Agricultural College } \\
\text { to develop sustainable farming standards. }\end{array}$ & $\begin{array}{l}\text { - Reduced the carbon impact of its packaging by } 15 \% \text { since } 2003 \text {. } \\
\text { - It has taken } 18 \text { million lorry miles off UK roads since } 2005 \text {, and by } \\
2011 \text { it has achieved a } 36 \% \text { reduction in transport emissions } \\
\text { compared to } 2005 \text {. } \\
\text { Focus: Reducing } \mathbf{C O}_{2} \text { in logistics and distribution through } \\
\text { external collaboration }\end{array}$ \\
\hline
\end{tabular}




\section{Conclusions, managerial implications, limitations and future research}

In this study, we have looked at different aspects of $\mathrm{CO}_{2}$ reduction by companies. In particular, we focused on the use of SC collaboration for achieving environmental sustainability. We first analysed two Indian suppliers' initiatives of reducing $\mathrm{CO}_{2}$ emissions in collaboration with their local suppliers and UK customers. Understanding the level of collaboration in these SCs has helped gain an insight into the importance of collaborative initiatives in setting up and maintaining their green SCs. Based on the analysis, we proposed a simple conceptual framework for the processes and drivers of SC collaboration; a key observation of such collaboration is information sharing. This finding is also confirmed by Ramanathan and Muyldermans (2010), who stressed that information exchange in SC collaborations, is indeed important. Our study sends strong indications that it is possible to successfully achieve and maintain green SCs by sharing not only technical information, such as product carbon footprints and supply schedules, but also the wider requirements of participants, green agendas, and strategies among all SC partners in such collaborative arrangements.

Moreover, businesses have different time scale to the implementation of identified green agendas in different areas of operations. Accordingly, we have suggested three levels of collaboration to improve sustainability in production, supply, distribution, material and technology, and other operations. Companies can apply these levels of collaboration in order to develop a common framework to achieve their green SCs. The companies with futuristic level of collaboration can focus on reducing carbon emission in both upstream and downstream supply chains such as supply side, manufacturing and distribution side. The companies with progressive collaboration can focus on $\mathrm{CO}_{2}$ reduction in internal operations and logistics distribution operations. But it is difficult for those companies to have a full control on supply side of operations. The companies with basic preparatory level of collaboration can start reducing carbon emission in its internal operations.

Subsequently, we looked at interview responses from sixteen UK logistics and transport companies. In particular, we examined how these companies view the various drivers they face for adopting green SCs. To provide a complete picture, we reviewed literature available in the public-domain, covering the range of activities underway or planned for $\mathrm{CO}_{2}$ reduction set by a number of the leading UK retailers. Most of the companies in the UK listed in Table 4 stress the importance of carbon reduction within their routine daily operations. SC collaboration can also reduce the carbon emission further in 
terms of raw-materials, production and delivery. Both intra- and inter- organisational collaboration are found essential for companies to be successful in maintaining the green SCs. The findings of this research are intended to assist managers in the following areas:

- Improve the involvement of SC players, by identifying possible relevant initiatives and strategies for reducing $\mathrm{CO}_{2}$ emissions.

- Improvement in production, raw-material use, and on-time replenishment to achieve reduced $\mathrm{CO}_{2}$ emissions.

- To plan and design information sharing, focusing on $\mathrm{CO}_{2}$ emission levels, among different SC members.

- To decide on the appropriate levels of collaboration along the SC.

To generalise the results of this study, it would be useful to widen the research to other industrial sectors, such as the SC of electrical and electronic products.

In conclusion, we point out that every business faces the difficult task of finding a balance between achieving business objectives and dealing with stakeholder pressures. With an increasing awareness of the need for ever-greener SCs, companies both in the UK and overseas are seeing collaboration in SC activities as one key factor in helping to achieve this difficult balance.

R2- Need some revision, look at the abstract, The conclusion should include findings from the empirical work e.g suppliers action to reduce $\mathrm{CO} 2$ emissions. This section should also include suggestions

- Overall suggestion for collaboration strategy

- $\quad$ Specific suggestion for suppliers - derived from cases

- $\quad$ Specific suggestion for logistics companies - derived from interviews

- $\quad$ Specific suggestion for retailers - derived from document study

- See comments for more details.

\section{References}

Alliance Boots (2012), "Building a Sustainable Group for a better World" - Alliance Boots Corporate Social Responsibility Report 2010/11. Available at: http://media.allianceboots.com/app_media/alliancebootscsr/home/pdfs/AllianceBoots CorporateSocialResponsibilityReport.pdf. [Accessed 22/10/2012]. 
ASDA (2011), "Sustainability 2.0 - Asda's Environmental Sustainability Targets 2010-2015: Our Public Commitments", available at: http://your.asda.com/system/dragonfly/production/2011/12/15/16_49_44_464_Asda_ 2_0_Sustainability_Strategy_updated.pdf. [Accessed 10/10/2012].

Aviv, Y. (2007). On the benefits of collaborative forecasting partnerships between retailers and manufacturers. Management Science Vol.53 No.5, pp.777-794.

Barratt, M. (2004). Understanding the meaning of collaboration in the supply chain. Supply Chain Management: An International Journal , Vol. 9 No.1, pp.30-41.

Barratt, M. and Oliveira, A. (2001). Exploring the experiences of collaborative planning initiatives. International Journal of Physical Distribution \& Logistics Management, Vol.31 No.4, pp. 266-289.

B\&Q (2012), “B\&Q’s One Planet Home Action Plan (January 2012) - Solutions for Sustainability", available at:

http://www.diy.com/diy/jsp/corporate/pdfs/bq_action\%20Plan.pdf. BioRegional Development Group.

BERR (Department for Business Enterprise \& Regulatory Reform) (2007), "WEEE Regulations 2006, Government Guidance Notes", available at: http://webarchive.nationalarchives.gov.uk/+/http://www.berr.gov.uk/files/file42909.p df [Accessed 12/09/2012].

BIS (Department for Business Innovation \& Skills) (2010), “The End of Life Vehicles Regulations 2003, 2005 and 2010, Government Guidance Notes", available at: http://www.bis.gov.uk/assets/biscore/business-sectors/docs/e/10-897-elv-regulationsguidance-june-2010.pdf [Accessed 26/10/2012].

BIS (Department for Business, Innovation \& Skills)(2012). "BIS Carbon Reduction Delivery Plan", March, 2012. http://www.bis.gov.uk/assets/BISCore/business-sectors/docs/10-787carbon-reduction-delivery-plan.pdf [Accessed 20/10/2012].

British Retail Consortium (2012), www.brc.org.uk, (Accessed 19/10/2012)

BSI (Department for Business Innovation \& Skills) (2011), "PAS 2050: 2011 - Specification for the assessment of the life cycle greenhouse gas emissions of goods and services", available at:

http://www.bsigroup.com/upload/Standards\%20\&\%20Publications/Energy/PAS2050. pdf [Accessed 20/10/2012].

CCC (Committee on Climate Change) (2008)," Building a Low Carbon Economy: the UK's Contribution to Tackling Climate Change", available at: http://www.theccc.org.uk/reports/building-a-low-carbon-economy [Accessed 20/04/ 2012].

Carter, C.R., Easton, P.L., 2011. Sustainable supply chain management: evolution and future directions. International Journal of Physical Distribution \& Logistics Management, Vol.41, pp.46-62. 
Chen, I.J. and Paulraj, A. (2004). Towards a theory of supply chain management: the constructs and measurements. Journal of Operations Management, Vol. 22, pp.119150.

Cherrett, T., Maynard, S., McLeod, F. and Hickford, A., (2010), "Reverse logistics for the management of waste", in McKinnon, A., Cullinane, S., Browne, M. and Whiteing, A. (Eds), Green Logistics: Improving the environmental sustainability of logistics. London: Kogan Page Limited, pp. 242-262.

Cullinane, S.L. and Edwards, J.B. (2010), “Assessing the Environmental Impacts of Freight Transport”, in McKinnon, A., Cullinane, S., Browne, M. and Whiteing, A. (Eds), Green Logistics: Improving the environmental sustainability of logistics. London: Kogan Page Limited, pp. 31-48.

Danese, P. (2007). Designing CPFR collaborations: insights from seven case studies. International Journal of Operations and Production Management Vol. 27 No.2, pp.181-204.

Dehning, B., Richardson, V.J. and Zmud, R.W. (2007), "The financial performance effects of IT-based supply chain management systems in manufacturing firms", Journal of Operations Management, Vol. 25 No. 4, pp. 806-824.

ECR, Europe (2002). European CPFR Insights, ECR European facilitated by Accenture, Brussels.

Edwards, J.B., Wang, Y., Potter, A. and Cullinane, S. (2010), "E-commerce, E-logistics and the Environment", in McKinnon, A., Cullinane, S., Browne, M. and Whiteing, A. (Eds), Green Logistics: Improving the environmental sustainability of logistics. London: Kogan Page Limited, pp. 322-338.

Eglese R. and Black, D. (2010), "Optimizing the routing of vehicles", in McKinnon, A., Cullinane, S., Browne, M. and Whiteing, A. (Eds), Green Logistics: Improving the environmental sustainability of logistics, London: Kogan Page Limited, pp. 322-338.

Ehrhart, C.E. (2010), Delivering Tomorrow: Towards Sustainable Logistics. Bonn: Deutsche Post AG.

Evans, J.R. (2007), "Impacts of information management on business performance", Benchmarking: An International Journal, Vol.14No.4, pp. 517-533.

Fisher, M.L., Hammond, J., Obermeyer, W. and Raman, A. (1997). Configuring a supply chain to reduce the cost of demand uncertainty. Production and Operations Management Vol. 6 No.3, pp.211-25.

Forme, F.G.L., Genoulaz, V.B., Campagne, J.P. (2007). A framework to analyse collaborative performance. Computers In Industry Vol.58, pp.687-97.

Horvath, L. (2001). Collaboration: The key to value creation in supply chain management. Supply Chain Management: An International Journal Vol.6 No.5, pp. 205.

John Lewis Partnership (2011), “A Clear View - Corporate Social Responsibility Report 2011”. JL Partnership House, available at:

http://www.johnlewispartnership.co.uk/csr.html [Accessed 20/10/2012]. 
Khan, O., Christopher, M and Creazza, A. (2012). Aligning product desing with the supply chain: a case study. Supply Chain Management: An International Journal Vol. 17 No. 3, pp. 323-336.

Larsen, T.S., Thenoe, C. and Andresen, C. (2003), "Supply chain collaboration: Theoretical perspectives and empirical evidence”, International Journal of Physical Distribution \& Logistics Management, Vol.33No.6, pp. 531-549.

Marchant, C. (2010), "Reducing the Environmental Impact of Warehousing" in McKinnon, A., Cullinane, S., Browne, M. and Whiteing, A. (Eds), Green Logistics: Improving the environmental sustainability of logistics. London: Kogan Page Limited, pp. 167-192.

McKinnon, A. (2010b), "Environmental Sustainability: A new priority for logistics managers",in McKinnon, A., Cullinane, S., Browne, M. and Whiteing, A. (Eds), Green Logistics: Improving the environmental sustainability of logistics. London: Kogan Page Limited, pp. 3-30.

McKinnon, A. (2010c), “Green Logistics: The Carbon Agenda”, LogForum, Vol.6No.3, pp. $1-9$.

McKinnon, A.C. (2010a), "The role of government in promoting green logistics", in McKinnon, A., Cullinane, S., Browne, M. and Whiteing, A. (Eds), Green Logistics: Improving the environmental sustainability of logistics. London: Kogan Page Limited, pp. 341-360.

McKinnon, A.C. and Edwards, J. (2010), “Opportunities for improving vehicle utilization", in McKinnon, A., Cullinane, S., Browne, M. and Whiteing, A. (Eds), Green Logistics: Improving the environmental sustainability of logistics. London: Kogan Page Limited, pp. 195-214.

New England Business Bulletin (2010), "Manufacturers to feel new pressure to go green", 27 June, 2010, available at: http://www.southcoasttoday.com/ [Accessed 12/09/2012].

Nyaga, G., Whipple, J., Lynch, D., 2010. Examining supply chain relationships: Do buyer and supplier perspectives on collaborative relationships differ? Journal of Operations Management, Vol. 28 No.2, pp. 101-114.

Oglethorpe, D. (2010), "Optimising economic, environmental, and social objectives: a goalprogramming approach in the food sector", Environment and Planning A, Vol.42No.5, pp. $1239-1254$.

Piecyk, M. (2010), "Carbon auditing of companies, supply chains and products”, in McKinnon, A., Cullinane, S., Browne, M. and Whiteing, A. (Eds), Green Logistics: Improving the environmental sustainability of logistics. London: Kogan Page Limited, pp. 49-67.

Ramanathan, U. (2012), "Supply chain collaboration for improved forecast accuracy of promotional sales", International Journal of Operations and Production Management, Vol.32No.6), pp. 676-695.

Ramanathan, U. and Muyldermans, L. (2010), "Identifying demand factors for promotional planning and forecasting: A case of a soft drink company in the UK", International Journal of Production Economics, Vol.128 No.2, pp. 538-545. 
Sari, K. (2008). On the benefits of CPFR and VMI: A comparative simulation study. International Journal of Production Economics, Vol.113 No. 2, pp. 575-586.

Sarkis, J., Zhu, Q., Lai, K.H., 2011. An organizational theoretic review of green supply chain management literature. International Journal of Production Economics, Vol. 130, pp.1-15.

Smaros, J. (2007). Forecasting collaboration in the European grocery sector: Observations from a case study. Journal of Operations Management, Vol. 25 No.3, pp. 702-716.

Simchi-Levi, D. and Zhao, Y. (2005). Safety Stock Positioning in Supply Chains with Stochastic Lead Times. Manufacturing \& Service Operations Management 7, 295-318.

Seuring, S., Müller, M., 2008. From a literature review to a conceptual framework for sustainable supply chain management. Journal of Cleaner Production Vol. 16, pp.1699-1710

Steckel, J.H., Gupta, S. and Banerji, A. (2004), "Supply Chain Decision Making: Will Shorter Cycle Times and Shared Point of Sale Information Necessarily Help?", Management Science, Vol.50 No.4, pp. 458-468.

Tesco (2011), “Corporate Responsibility Report 2011, Tesco PLC”, available at: http://www.tescoplc.com/media/60113/tesco_cr_report_2011_final.pdf [Accessed 16/10/2012].

Tesco News releases (2012), "Tesco wins Green Retailer of the Year at the Grocer Gold Awards", available at: http://www.tescoplc.com/index.asp?pageid=17\&newsid=644. [Accessed 22/10/2012].

UNFCCC (United Nations Framework Convention on Climate Change) (1997), "Kyoto Protocol to the United Nations Framework Convention on Climate Change",available at: http://unfccc.int/kyoto_protocol/items/2830.php [Accessed 14/04/2012].

United Biscuits (2012), "Environmental Sustainability", available at: http://www.unitedbiscuits.com/sustainability.php. [Accessed 08/09/2012].

Vachon, S. and Klassen, R.D. (2006), "Extending green practices across the supply chain: The impact of upstream and downstream integration", International Journal of Operations \& Production Management, Vol.26No.7, pp. 795 - 821.

Vachon, S. and. Klassen, R.D. (2008), "Environmental management and manufacturing performance: The role of collaboration in the supply chain", International Journal of Production Economics, Vol.111No.2, pp. 299-315.

Van Hoek, R.I. and Chapman, P. (2007), "How to move supply chain beyond cleaning up fter new product development", Supply Chain Management: An International Journal, Vol. 12 No. 4, pp.239-44.

Walker, H., Di Sisto, L., McBain, D., 2008. Drivers and barriers to environmental supply chain management practices: Lessons from the public and private sectors. Journal of Purchasing and Supply Management Vol.14, pp.69-85. 
Wal-Mart Stores Inc. (2010) "Wal-mart 2010 global sustainability report", available at http://cdn.walmartstores.com/sites/sustainabilitityreport/2010/WMT2010GlobalSust [Accessed 12/09/2012].

Wu, H.-J. and Dunn, S.C. (1995), "Environmentally Responsible Logistics Systems", International Journal of Physical Distribution, Vol.25 No.2, pp. 20-38. 